\title{
The impact of digitization on the religious sphere: televangelism as an example
}

\author{
Shaimaa El Naggar \\ Lancaster University and Fayoum University \\ E-mail:s.elnaggar@lancaster.ac.uk; shaimma@hotmail.com
}

\begin{abstract}
Televangelism as one example of digital media technology is popular as a media of preaching recently. Televangelism is a hybrid genre of religion and entertainment which can be the manifestation of 'infotainment' predominance in contemporary media culture. Televangelists use digital media technologies, such as the Internet, DVDs and blogspots to popularize their programmes. They, therefore, raise their popularity and are granted a 'celebrity status' by having thousands of fans and followers on social media networks. The findings show that Televangelism becomes popular among Muslim youth audiences because they perceive it as a new form of religious expression which is considered 'modern' in appearance and relevant to their everyday lives. For them, Televangelism is also a manifestation of the individual change. This study shows that with the rise of literacy rate and the availability of modern digital media, religious knowledge became accessible to large community. The internet has become a new paradigm where voices can compete for the authority. The cyberspace and internet have become one important platform where religious can be disseminated, contested and negotiated easily. Therefore, televangelists have become influential figures to some Muslim audiences, especially the youth in middle classes. The use of digital media by televangelists
\end{abstract}


has helped popularize their discourses. The findings also shows how the sermons and texts of particular televangelists can possibly relate to dominant (capitalist) ideologies, how structures of power are represented in their discourses and what their texts may reveal about the socio-historical contexts of Muslims in the twenty first century.

Televangelisme sebagai salah satu contoh teknologi media digital populer merupakan media khutbah baru-baru ini. Televangelisme adalah suatu genre hibrida antara agama dan entertainment yang dapat menjadi manifestasi dari 'infotainment' yang dominan dalam kebudayaan media kontemporer. Televangelis menggunakan teknologi media digital, seperti internet, DVD dan blogspots untuk mempopulerkan program mereka. Oleh karena itu, teknologi ini dapat meningkatkan popularitas mereka dan memberikan 'status selebriti' oleh ribuan penggemar dan pengikut di jejaring media sosial. Temuan ini menunjukkan bahwa televangelisme menjadi populer di kalangan penonton muda Muslim karena mereka menganggap hal itu sebagai bentuk baru ekspresi keagamaan yang lebih modern dalam penampilan dan relevan dengan kehidupan sehari-hari mereka. Bagi mereka, Televangelisme juga merupakan manifestasi dari perubahan individu. Studi ini menunjukkan bahwa dengan munculnya tingkat melek huruf dan ketersediaan media digital modern, ilmu agama menjadi diakses komunitas lebih luas. Internet telah menjadi paradigma baru di mana banyak suara berkompetisi untuk memperoleh otoritas. Dunia maya dan internet telah menjadi platform yang penting di mana agama dapat disebarluaskan, diperebutkan dan dinegosiasikan dengan mudah. Televangelis telah menjadi tokoh berpengaruh bagi sebagian penonton Muslim, khususnya kaum muda di kelas menengah. Penggunaan media digital oleh televangelis telah membantu mempopulerkan wacana mereka. Temuan ini juga menunjukkan bagaimana khutbah dan teks televangelis mungkin dapat berhubungan dengan idelologi dominan (kapitalis), dan menstrukturasi kekuasaan yang terwakili dalam wacana mereka dan apa yang mereka nyatakan tentang konteks sosio-historis umat Islam di abad kedua puluh satu.

Keywords: Televangelism; Digital media technology; Religion; Infotainment 


\section{Introduction}

The proliferation of digital media technologies in the twenty first century has its impact on mediated communication in the public sphere; this can be exemplified in the domain of politics ${ }^{1}$ and religion. ${ }^{2}$ In 'global religions' such as Judaism, Christianity, Islam and Buddhism, ${ }^{3}$ digitization has opened up new spaces for the mediation of religious information. ${ }^{4}$ The Internet, for instance, has enabled particular religious communities ${ }^{5}$ to circulate and publicize their message. The proliferation of religious websites, forums and blogs, e-books and DVDs of religious material came to be known as e-religion. ${ }^{6}$

Within the above context, one phenomenon that has gained popularity in recent years is televangelism, in which satellite television/Internet is used as a medium of preaching. ${ }^{7}$ Historically speaking, televangelism

\footnotetext{
${ }^{1}$ R. Wodak, B. Mral \& M. Khosravinik (eds.), Right Wing Populism in Europe: Politics and Discourse. London: Bloomsbury Academic, 2013, on the use of internet by right-wing politicians.

${ }^{2}$ G. Bunt, Islam in the Digital Age: E-jihad, Online Fatwas and Cyber Islamic Environments, London: Pluto Press, 2003; G. Bunt, "Rip, Burn, Pray: Islamic Expression Online", in Dawson, L. L. and D. E. Cowan (eds.), Religion Online: Finding Faith on the Internet, London and New York: Routledge, 2004, 123-134.

${ }^{3}$ Mark Juergensmeyer (ed.), Global Religions: An Introduction, Oxford: Oxford University Press, 2003.

${ }^{4}$ H.A. Campbell, "Understanding the Relationship between Religion Online and Offline in a Networked Society", Journal of the American Academy of Religion, Vol. 80, No. 1 (2012), 64-93; K. Tartoussieh, "Muslim digital Diasporas and the gay pornographic cyber imaginary", in E. Alsultany and E. Shohat (eds.) Between the Middle East and the Americas: The Cultural Politics of Diaspora, USA: University of Michigan Press, 2013, 214-230.

${ }^{5}$ e.g. Protestant groups.

${ }^{6}$ C. Helland, "Popular religion and the World Wide Web: A match made in (Cyber) Heaven", in L.L. Dawson, and D. E. Cowan, Religion Online: Finding Faith on the Internet. London and New York: Routledge, 2004, 23-36; H.A. Campbell, When Religion Meets New Media, London: Routledge, 2010; H.A. Campbell, "Understanding the Relationship between Religion Online and Offline in a Networked Society", Journal of the American Academy of Religion, Vol. 80, No. 1 (2010), 64-93.

${ }^{7}$ Bruce, S., Pray TV: Televangelism in America, London: Routledge, 1990; H.A. Campbell, When Religion Meets New Media, London: Routledge, 2010; K. Tartoussieh, "Muslim digital
} 
IJIMS, Indonesian Journal of Islam and Muslim Societies, Volume 4, Number 2, December 2014: 189-211

rose into prominence in the 1980s in the United States of America due to the popularity of some figures such as Jerry Falwell, Pat Robertson and James Robinson. ${ }^{8}$ It soon spread to Muslim majority and minority contexts, for instance, in Egypt and Indonesia as well as in the United Kingdom and the United States of America. ${ }^{9}$

Televangelism is interesting in many ways. It is a hybrid genre of religion and entertainment and can be conceived of as one manifestation of the predominance of 'infotainment' in contemporary media culture. ${ }^{10}$ In addition, it is a manifestation of the rise of the celebrity culture. ${ }^{11}$ In a similar way to public figures such as popular artists and politicians, televangelists have become 'media celebrities' with thousands of fans and followers on social media networks.

While television is a main medium for disseminating televangelists' programmes, I argue in this paper that digital media technologies, such as the Internet, DVDs and blogspots, represent one important paradigm that has helped popularize televangelists' programes, granting them a

Diasporas and the gay pornographic cyber imaginary", in E. Alsultany and E. Shohat (eds.) Between the Middle East and the Americas: The Cultural Politics of Diaspora, USA: University of Michigan Press, 2013, 214-230.

${ }^{8}$ R. Frankl, Televangelism: The Marketing of Popular Religion, The United States of America: Southern Illinois University Press, 1987, 3-8; S. Bruce, Pray TV: Televangelism in America, London: Routledge, 1990.

${ }^{9}$ R. Frankl, Televangelism: The Marketing of Popular Religion. The United States of America: Southern Illinois University Press, 1987; S. Gilliat-Ray, Muslims in Britain: An Introduction, Cambridge: Cambridge University Press, 2010, 162; and N. Echchaibi, "From audio tapes to video blogs: the delocalization of authority in Islam. Nations and Nationalism, Vol. 17, No. 1 (2011), 25-44.

${ }^{10}$ See L. Van Zoonen, "Imagining the Fan Democracy", European Journal of Communication 19 (2004), 39-52; L. Van Zoonen, Entertaining the Citizen: When Politics and Popular Culture Converge, New York: Rowman \& Littlefield, 2005; and R. Wodak, The Discourse of Politics in Action: Politics as Usual, Basingstoke: Palgrave Macmillan, 2009, on 'politicotainment'.

${ }^{11}$ A. Jaffe, Modernism and the Culture of Celebrity, Cambridge: Cambridge University Press, 2005; D. Rockwell, and D. C. Giles, "Being a Celebrity: A Phenomenology of Fame", Journal of Phenomenological Psychology 40 (2009), 178-210. 
'celebrity status'. Related to the above is the impact of digitization on the deconstruction of traditional sources of religious authority in the twenty first century, televangelism being one of its important manifestations.

Thematically, the present study is divided into two sections. First, I delineate the main features of televangelism and give account of the use of digital media by two popular televangelists, namely Amr Khaled and Hamza Yusuf. ${ }^{12}$ Then, I explore the important question as to how digitization has changed the structure of religious authority in the twenty first century. ${ }^{13}$

\section{Tele vangelism: a new form of religious expression}

There are many characteristic features of televangelism that have rendered it a new form of religious expression. One feature is the hybridity of the genre in which entertainment elements- such as the use of songs and/or talk shows- are integrated into religious messages ${ }^{14}$. In addition, unlike formally educated scholars who are dressed in traditional garb

12 See W. Lotfy, The Phenomenon of Televangelists. Cairo, Egypt: Dar El Ein, 2009; L. Wise, "Words from the Heart: New Forms of Islamic Preaching in Egypt", Masters thesis, St Anthony's College, University of Oxford, 2003. Available at: http://users.ox.ac.uk/ metheses/WiseNoImages.pdf (accessed 22nd February 2014). on Amr Khaled; S. GilliatRay, Muslims in Britain: An Introduction, Cambridge: Cambridge University Press, 2010; and John L. Esposito and Kalin (eds.), The 500 Most Influential Muslims in the World, Amman: The Royal Islamic Strategic Studies Centre, 2009, see on Hamza Yusuf.

${ }^{13}$ Martin van Bruinessen, "Making and unmaking Muslim religious authority in Western Europe", Paper presented at the Fourth Mediterranean Social and Political Research Meeting, Florence \& Montecatini Terme, 19-23 March, 2003, Robert Schuman Centre for Advanced Studies at the European University Institute; B. Turner, "Religious Authority and the New Media", Theory Culture Society 24 (2007), 117; V. Sisler, "The Internet and the construction of Islamic knowledge in Europe. Masaryk University", Journal of Law and Technology, Vol. 1, No. 2 (2007); and J. Kutscher, The Politics of Virtual Fatwa Counseling in the 21st Century", Masaryk University Journal of Law and Technology, Vol. 3, No. 1 (2009), 33-50.

${ }^{14}$ See L. Wise, "Words from the Heart: New Forms of Islamic Preaching in Egypt", Masters thesis, St Anthony's College, University of Oxford, 2003. Available at: http:// users.ox.ac.uk/ metheses/WiseNoImages.pdf (accessed 22nd February 2014); and W. Lotfy, The Phenomenon of Televangelists, Cairo, Egypt: Dar El Ein, 2009. 
IJIMS, Indonesian Journal of Islam and Muslim Societies, Volume 4, Number 2, December 2014: 189-211

and use classical Arabic ${ }^{15}$, televangelists make use of colloquial and conversational style and wear modern clothes.

Moreover, characteristic of televangelists' discourses is the presentation of religion as a source of individual change ${ }^{16}$. To illustrate, the televangelist Amr Khaled, one case study I draw on below, calls upon his audiences to dismiss pessimism and take part in civic action ${ }^{17}$. For instance, in his programmes, Khaled calls upon his audiences to volunteer to the organization he established i.e. Life Makers ${ }^{18}$, which is aimed, inter alia, at fighting illiteracy and drugs.

In the same vein, in Indonesia, the two popular televangelists, Aa Gym and Arifin IIham, commodify religion as a means of personal development. ${ }^{19}$ Aa Gym, for instance, integrates his religious message with advices on personal development and business management (e.g. promoting communicative skills and networking. He has three mottos: 'start with yourself, 'start with small things' and 'start now'. ${ }^{20}$

The above features are reasons why televangelism is particularly appealing to some audiences of Muslim youth who perceive televangelism as a new form of religious expression that is both 'modern' in appear-

${ }^{15} \mathrm{~K}$. Tartoussieh, "Muslim digital Diasporas and the gay pornographic cyber imaginary", in E. Alsultany, and E. Shohat (eds.) Between the Middle East and the Americas: The Cultural Politics of Diaspora, USA: University of Michigan Press, 2013, 221.

${ }^{16}$ J.D. Howell, "Modulations of active piety: Professors and televangelists as promoters of Indonesian 'Sufisme", in Fealy, G. and S. White. Expressing Islam: Religious Life and Politics in Indonesia, Institute of Southeast Asian Studies, 2008, 40-62.; W. Lotfy, The Phenomenon of Televangelists, Cairo, Egypt: Dar El Ein; 2009; N. Echchaibi, "From audio tapes to video blogs: the delocalization of authority", in Islam, Nations and Nationalism, Vol. 17, No. 1 (2011), 25-44.

${ }^{17}$ W. Lotfy, The Phenomenon of Televangelists..., 17; and J. Kutscher, "The Politics of Virtual Fatwa ..., 33.

${ }^{18}$ The link to the organization: http://lifemakers.org/

${ }^{19}$ See J.D. Howell, "Modulations of active piety: Professors and televangelists as promoters of Indonesian 'Sufisme”, in Greg Fealy, and S. White, Expressing Islam: Religious Life and Politics in Indonesia, Institute of Southeast Asian Studies, 2008, 52-58.

${ }^{20}$ J.D. Howell, "Modulations of active piety..., 55-58. 
ance and relevant to their everyday lives. ${ }^{21}$

In addition, I argue that the use of digital media technologies has granted televangelism more popularity and visibility. ${ }^{22}$ In the coming sections, I draw on two case ${ }^{23}$ studies: the Egyptian televangelist Amr Khaled who has huge following among young Muslims in the Arab world and the Middle East ${ }^{24}$ and the American televangelist Hamza Yusuf who is particularly popular among young western Muslims. ${ }^{25}$ The point of integrating two case studies is to build up on scholarly research on Islam in a global context, ${ }^{26}$ rather than solely focusing on Islam in 'old' majority settings. ${ }^{27}$

In the following, I start by giving a short bio-graphical note about Amr Khaled, before exploring how digital media has consolidated his popularity.

${ }^{21}$ See L. Wise, "Words from the Heart: New Forms of Islamic Preaching in Egypt". Masters thesis, St Anthony's College, University of Oxford. 2003. Available at: http:// users.ox.ac.uk/ metheses/WiseNoImages.pdf (accessed 22nd February 2014); W. Lotfy, W. The Phenomenon of Televangelists, Cairo, Egypt: Dar El Ein, 2009; N. Echchaibi, "From audio tapes..., 25-44.

${ }^{22}$ K. Tartoussieh, "Muslim digital Diasporas..., 220.

${ }^{23}$ Following G. Thomas, "A typology for the case study in social science following a review of definition, discourse and structure", Qualitative Inquiry, Vol. 17, No. 6 (2011), 513, I define a case study as: 'Analyses of persons, events, decisions, periods, projects, policies, institutions, or other systems that are studied holistically by one or more methods'.

${ }^{24}$ H.A. Campbell, When Religion Meets New Media..., 92 and L. Wise, "Words from the Heart: New Forms of Islamic Preaching in Egypt", Masters thesis, St Anthony's College, University of Oxford. 2003. Available at: http://users.ox.ac.uk/ metheses/ WiseNoImages.pdf (accessed 22nd February 2014).

25 John L. Esposito and Kalin (eds.), The 500 Most Influential Muslims in the World, Amman: The Royal Islamic Strategic Studies Centre, 2009; also see S. Gilliat-Ray, Muslims in Britain..., 166.

26 See Y.Y. Haddad, and J.I. Smith (eds.), Muslim minorities in the West: Visible and Invisible, Oxford: Altamira Press, 2002; and P. Mandaville, "Towards a critical Islam: European Muslims and the changing boundaries of transnational religious discourse", in S. Allievi, and J. Nielsen (eds.), Muslim Networks and Transnational Communities in and across Europe, Leiden: Brill, 2003.

27 e.g. see J.R. Hinnells, "The study of diaspora religion", in J.R. Hinnells, (ed.), The Penguin Handbook Of The World's Living Religions, London: Penguin, 2010, 683. 


\section{The case study of Amr Khaled}

Born in 1967, Amr Khaled graduated with a BA in accounting in 1988. While still working as an accountant, he began preaching in mosques in 1990. In 1998, he moved to full-time preaching, primarily on satellite television. ${ }^{28}$ DVDs of Khaled's first programme 'Words from the Heart' were distributed to street vendors in Cairo, hitting 50,000 copies in 2001. ${ }^{29}$ His programme was soon taken up by the satellite television channel Dream TV and the Saudi channel Iqraa. ${ }^{30}$

It is the skillful use of digital media that has sustained his popularity. For instance, he set up a website 'amrkaled.net'; recognized as 'one of the most popular Arab sites worldwide', where Khaled offers 'video downloads of his sermons, MP3s of popular religious music, printed transcripts of TV shows and numerous other resources for young followers' ${ }^{31}$ Moreover, in an attempt to achieve a 'transnational' reach, his website has versions in nineteen different languages including English, Chinese, Russian and Urdu. ${ }^{32}$

In addition, YouTube emerges as an important channel for the mediation of Khaled's programmes. This can be contextualized in the popularity of YouTube itself as an online channel. ${ }^{33}$ It is one of the most rapidly growing video-sharing websites on the Internet: there is no limit to the number of YouTube videos that a user can create and download; it also has some 'community' features for instance, creating/following particular

${ }^{28}$ http://amrkhaled.net/ak_private

${ }^{29}$ H.A. Campbell, When Religion Meets New Media...,92.

${ }^{30}$ H.A. Campbell, When Religion Meets New Media..., 92.

${ }^{31}$ H.A. Campbell, When Religion Meets New Media..., 92.

${ }^{32}$ H.A. Campbell, When Religion Meets New Media...,92.

${ }^{33}$ J. Burgess, and J. Green, You Tube: Online Video and Participatory Culture. Cambridge: Polity, 2009; A. Keen, How Today's Internet is killing Our Culture and Assaulting Our Economy, Great Britain, Nicholas Brealey Publishing, 2007. 
YouTube channels and commenting on videos posted by other users. ${ }^{34} \mathrm{On}$ his YouTube channel, ${ }^{35} \mathrm{Amr}$ Khaled posts excerpts and/or sound bites of his programmes and updates of his recent visits. One aspect that is worth noting is that Khaled himself highlights his use of new media. For instance, in footage of a visit by Khaled to China, published on his YouTube channel, he is seen giving a lecture; as Twitter users, on the left hand side, interact with him on Twitter (Figure 1).

\section{Figure 1}

Footage of Khaled's talk in China mediated on his YouTube channel

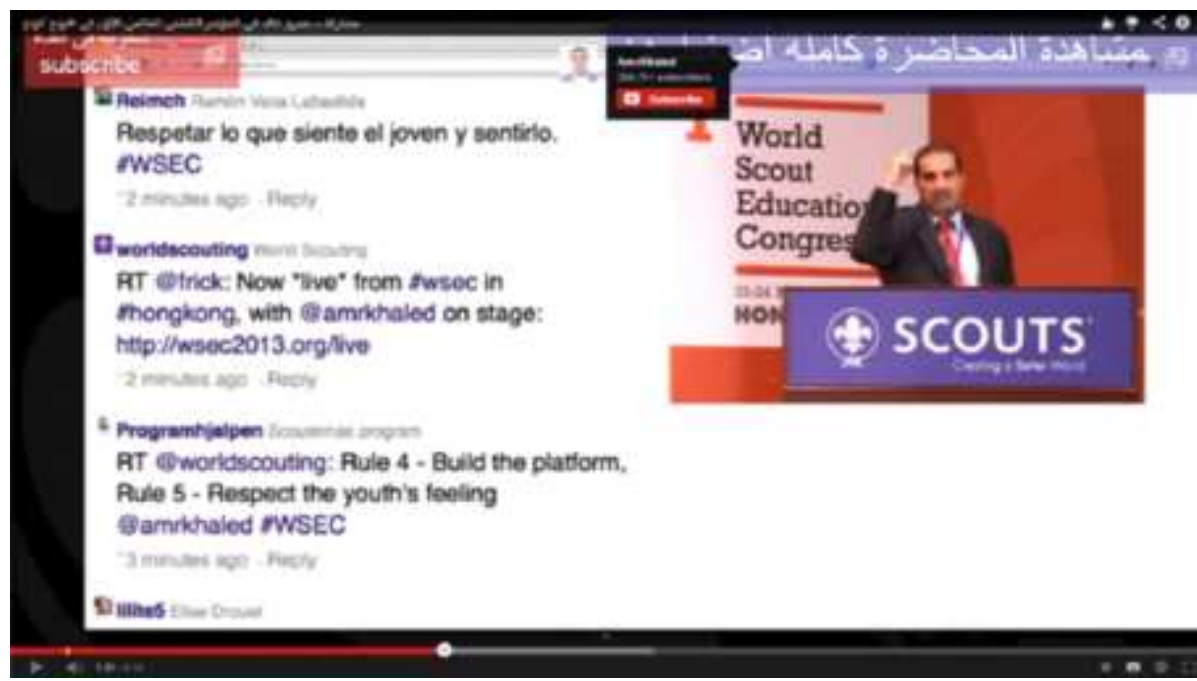

In addition to his YouTube channel, Amr Khaled has a Facebook page that has a high record of subscribers as eight million fans. ${ }^{36}$ In fact,

${ }^{34}$ A. Keen, How Today's Internet..., 10-14; J. Burgess, and J. Green, You Tube: Online Video..., 1-6 on the features of YouTube.

${ }^{35}$ Link to Amr Khaled's YouTube channel: http://www.youtube.com/user/AmrKhaled.

${ }^{36}$ Link to Amr Khaled's Facebook page: https://www.facebook.com/AmrKhaled?v=info 
IJIMS, Indonesian Journal of Islam and Muslim Societies, Volume 4, Number 2, December 2014: 189-211

Facebook is one important channel where Khaled interacts with his audiences and gains online visibility. This can be illustrated by examining one of Khaled's posts ${ }^{37}$ on Facebook (Figure 2).

\section{Figure 2}

One post of Amr Khaled on his Facebook page, published 23 ${ }^{\text {rd }}$ Dec. 2013

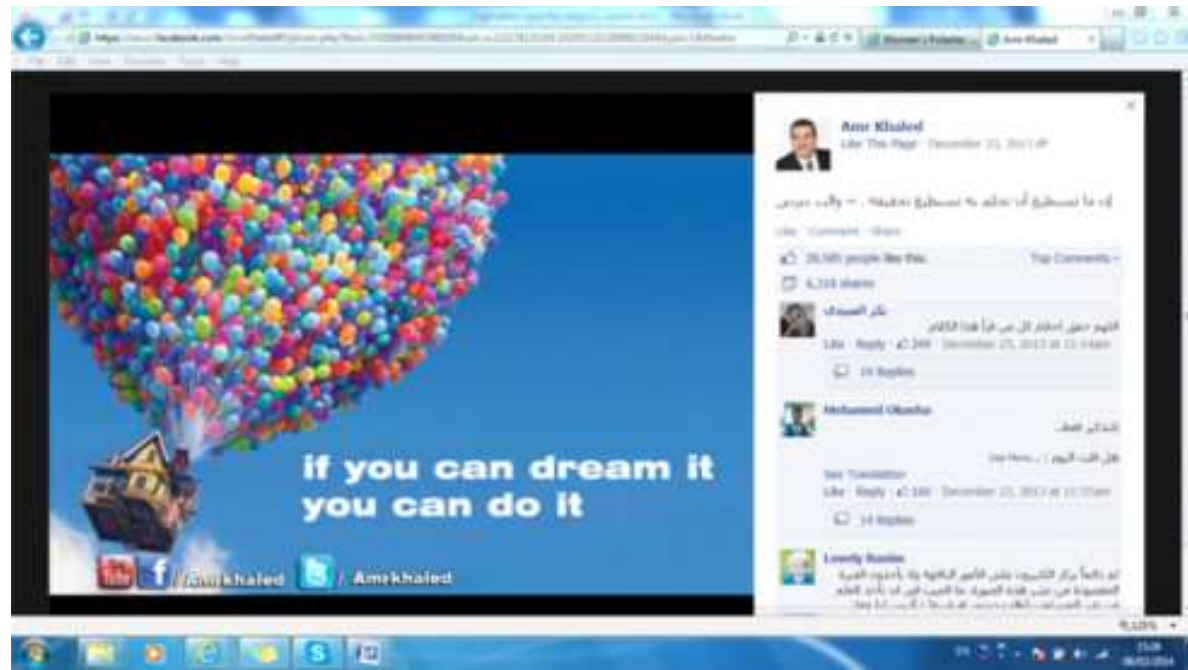

There are many textual and multi-modal aspects that are worth examining in the above post (Figure 2). The use of the quotation in English accompanied by an Arabic translation on the right hand side- indicates Khaled's attempt to reach audiences that do not necessarily read Arabic. In addition, the recontextualisation of a quotation by Walt Disney, basically a non-religious figure, shows an attempt to integrate both religious and non-religious messages or as Hashem put it, to create 'a civil-religious nexus'. In fact, the quotation here 'if you can dream it, you can do it' acts as an 'anchorage' to the image of the colorful flying balloon, ${ }^{38}$ sending a

${ }^{37}$ The post is published on 23rd December 2013.

${ }^{38}$ See G. Rose, Visual Methodologies: an Introduction..., 87 
message of hope to the audiences.

Interestingly, the fact that Khaled's post is shared, to date, by about six thousand users on Facebook, lends truth to how social media has helped extend Khaled's online visibility among his fans, followers and their network of friends.

The use of digital media is an important dynamics of televangelism not only in Muslim majority contexts ${ }^{39}$ but also in minority contexts such as the United Kingdom and the United States of America. ${ }^{40}$

In this vein, one salient example is the American televangelist Hamza Yusuf, described in Esposito and Kalin's ${ }^{41}$ book 500 Most Influential Muslims as 'the Western world's most influential Islamic scholar who has built a huge grassroots following, particularly among young western Muslims'. In the following, I start by presenting bio-information about Yusuf before examining how the use of new media has consolidated his popularity.

\section{The case study of Hamza Yusuf}

Born in 1958 in the United States of America, and a convert to Islam, Hamza Yusuf has the title of an 'Islamic scholar' and 'an intellectual'42. He has established one college in California, the Zaytuna College, which aims to 'train students in the varied sciences of Islam, while also instilling in them a sophisticated understanding of the intellectual history and culture of the West' ${ }^{43}$.

Giving his sermons and programmes in English, primarily addressing the English-speaking communities, Yusuf focuses on issues of Muslims in the West. Characteristic of Yusuf's discourse is that he calls upon Muslims

\footnotetext{
${ }^{39}$ H.A. Campbell, When Religion Meets New Media, London: Routledge, 2010, 89-96.

${ }^{40}$ See N. Echchaibi, "From audio tapes..., 25-44.

${ }^{41}$ John L. Esposito and Kalin, 500 Most Influential Muslims..., 78.

${ }^{42}$ S. Gilliat-Ray, Muslims in Britain..., 166 on Hamza Yusuf.

${ }^{43}$ The website of Zaytuna college: http://www.zaytunacollege.org/about/
} 
IJIMS, Indonesian Journal of Islam and Muslim Societies, Volume 4, Number 2, December 2014: 189-211

to 'rise up to the challenge'; taking a global perspective on problems such as poverty, disease in Africa and global economic injustices ${ }^{44}$. In addition, he reiterates in his sermons that he is both American and Muslim, dismissing discourses that represent Islam and the West as an oxymoron, i.e. if you are one you cannot be the other. ${ }^{45}$

Like the televangelist Amr Khaled, Yusuf makes use of a variety of digital media tools for a wider mediation of his discourses. One point that is worth noting here is how Hamza Yusuf's fans and followers make use of online spaces to popularize his discourses. For instance, figure 3 below shows one blogger who has dedicated her blogspot to Hamza Yusuf; ${ }^{46}$ the introduction to the blog reads: 'How my sister and I rediscovered the traditional Islamic knowledge our forefathers used to teach thanks to the lectures and writings of Shaykh Hamza Yusuf and how this journey changed our lives'.

Figure 3

One blogger dedicating her blog to Hamza Yusuf

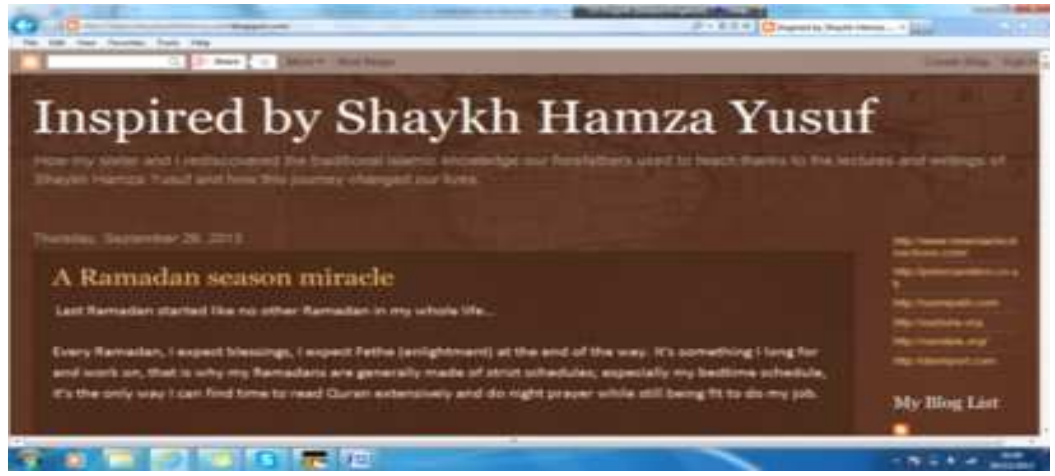

44 See El Naggar 2012.

${ }^{45}$ See P. Baker, C. Gabrielatos, \& T. McEnery, Discourse Analysis and Media Attitudes: The Representation of Islam in the British Press, Cambridge: Cambridge University Press, 2013; R. Wodak, Mral, B., \& M. Khosravinik, (eds.), Right Wing Populism in Europe: Politics and Discourse, London: Bloomsbury Academic, 2013.

${ }^{46}$ Link to the blog: http://inspiredbyshaykhhamzayusuf.blogspot.com/ 
Through the use of digital media, therefore, televangelists such as Amr Khaled and Hamza Yusuf have acquired 'transnational' popularity. To illustrate, in her ethnographic study on young Muslim youth in Sweden, Denmark and the United States of America, Schmidt cites the example of Aysha, a young woman from Sweden, whose dream is to travel to California to join Zaytuna College established by Hamza Yusuf. Transnational ties among Muslim youth, Schmidt argues, operates at a local level by inviting speakers from abroad, where teaching material often consists of downloaded texts produced by scholars such as Hamza Yusuf. ${ }^{47}$ This can be perceived within the context of an increasing use of the Internet by Muslim youth in Europe to seek religious knowledge. ${ }^{48}$

It is important to state here that the rise of televangelism, as a religious phenomenon, has to be seen within the wider context of the deconstruction of the traditional sources of religious authority. ${ }^{49}$ With the emergence of 'digital Islam' ${ }^{50}$ new paradigms ${ }^{51}$ have emerged in which many voices are competing for authority. I explore this point in the following section.

${ }^{47}$ G. Schmidt, "The Transnational Umma- Myth or Reality? Examples from the Western Diasporas", The Muslim World 95 (2005), 575-586.

${ }^{48} \mathrm{~V}$. Sisler, "The Internet and the Construction of Islamic Knowledge in Europe", Masaryk University Journal of Law and Technology, Vol. 1, No. 2 (2007); P. Mandaville, "Towards a Critical Islam..., 129; S. Gilliat-Ray, Muslims in Britain..., 166.

${ }^{49}$ Martin van Bruinessen, "Making and Unmaking Muslim Religious Authority in Western Europe”, Paper presented at the Fourth Mediterranean Social and Political Research Meeting, Florence \& Montecatini Terme, 19-23 March, 2003, Robert Schuman Centre for Advanced Studies at the European University Institute; V. Sisler, V. The Internet and the Construction of Islamic Knowledge in Europe", Masaryk University Journal of Law and Technology, Vol. 1, No. 2 (2007); and B.S. Turner, "Religious Authority and the New Media", Theory Culture Society 24 (2007), 117.

${ }^{50}$ G. Bunt, Islam in the Digital Age: E-jihad, Online Fatwas and Cyber Islamic Environments, London: Pluto Press, 2003; and M. El-Nawawy, and S. Khamis. Islam Dot Com: Contemporary Islamic Discourses in Cyberspace, New York: Palgrave Macmillan, 2009.

${ }^{51}$ e.g. online magazines, publishing houses. 


\section{Digitization and the deconstruction of religious authority}

In order to understand how televangelists have become sources of authority for wider constituencies of audiences in the contemporary age, one has to explore the traditional sources of religious authority in Islam.

For long, the dissemination of religious knowledge was under the authority of formally educated scholars, or ulama as students relied on an oral tradition where they studied religion through the memorization of the Quran and the Prophet's sayings ${ }^{52}$. The advent of print capitalism to the Muslim world in the nineteenth century, however, marked an important stage in the change in religious authority as religious texts became accessible to larger constituencies of readers. This in a way, Eickelman argued (1982), has extended the control of the ulama, formally educated scholars, on the dissemination of religious knowledge.

However, with the rise of literacy rates and the availability of religious texts-now in print form- religious knowledge became accessible to larger constituencies of readers who can now 'read' and 'interpret'. As Robinson put it, 'Books . . . could now be consulted by any Ahmad, Mahmud or Muhammad, who could make what they [would] of them'. ${ }^{53}$

If print capitalism has broken the monopoly of religious scholars on Islamic knowledge, the predominance of digital media has even accelerated the dynamics of accessing religious texts. Through CDs, websites, blogs and forums ${ }^{54}$ works of exegesis and jurisprudence can be stored and

${ }^{52}$ F. Robinson, "Islam and the Impact of Print", Modern Asian Studies, Vol. 27, No. 1 (1993), 245; D.F. Eickelman, "The Study of Islam in Local Contexts", Contributions to Asian Studies (1982), 10; and P. Mandaville, "Reimagining Islam in Diaspora: The Politics of Mediated Community”, International Communication Gazette Vol. 63, No. 2-3 (2010), 176 180.

${ }^{53}$ F. Robinson, "Islam and the Impact of Print..., 245.

${ }^{54}$ G. Bunt, G. Islam in the Digital Age: E-jihad, Online Fatwas and Cyber Islamic Environments, London: Pluto Press, 2003; and M. El-Nawawy and S. Khamis, Islam Dot Com: Contemporary Islamic Discourses in Cyberspace, New York: Palgrave Macmillan, 2009. 
accessed by users in multi-media format. ${ }^{55}$

In addition, the Internet has become a new paradigm where voices can compete for authority. One stark example in this vein is the issuing of fatwas, i.e. authoritative opinions, online ${ }^{56}$. Whereas in the past, one traditional route for getting fatwas was accessing educational institutions or formally educated scholars, fatwas can now be offered through websites ${ }^{57}$ where answers to questions are responded to by scholars associated with the website. ${ }^{58}$ This means that new media has opened up new spaces where varied actors can claim religious authority.

This applies to Muslim majority and minority contexts. ${ }^{59}$ Sisler (2007), for example, shows how fatwas posted in English, seem to particularly address issues of Muslims in Europe and the United States. ${ }^{60}$ For instance, he cites the case of one Fatwa issued by the European Council for Fatwa and Research which -unlike one reading of Islamic law- has permitted the use of a loan in order to solve one's housing situation. ${ }^{61}$ Published by Islamonline.net and Ukim.org, the fatwa has triggered a debate on cyberspace, and 'has clearly influenced subsequent fatwas, for example one issued later by AlAzhar. ${ }^{62}$ The latter example not only testifies to the creation of a global 'public sphere' where some Islamic interpretations may be discussed, negotiated and contested in chat rooms and websites across the board ${ }^{63}$ but

${ }^{55}$ P. Mandaville, "Reimagining Islam in Diaspora: The Politics of Mediated Community", International Communication Gazette, Vol. 63, No. 2-3 (2001), 178.

${ }^{56} \mathrm{~V}$. Sisler, "The Internet and the Construction..., 206.

${ }^{57}$ e.g. Islamonline.net; Islamcity.com

${ }^{58}$ V. Sisler, "The Internet and the Construction..., 206.

59 P. Mandaville, "Reimagining Islam in Diaspora..., 177; J. Kutscher, "The Politics of Virtual Fatwa ..., 33-50.

${ }^{60}$ V. Sisler, "The Internet and the Construction..., 209.

${ }^{61} \mathrm{~V}$. Sisler, "The Internet and the Construction...,3.

${ }^{62} \mathrm{~V}$. Sisler, "The Internet and the Construction..., 3.

${ }^{63}$ V. Sisler, "The Internet and the Construction..., 3; P. Mandaville, "Reimagining Islam in Diaspora..., 177; Martin van Bruinessen, "Making and Unmaking Muslim Religious Authority in Western Europe", Paper presented at the Fourth Mediterranean Social and 
IJIMS, Indonesian Journal of Islam and Muslim Societies, Volume 4, Number 2, December 2014: 189-211

also demonstrates that Islam in Europe can shape and/or reshape the dominant interpretations of Islam in some Muslim majority contexts.

Whether fatwas are issued by religious institutions such as Al Azhar University or independent organizations such as the European Council for Fatwa and Research, the cyberspace has become one important platform where religious knowledge can be disseminated, contested and negotiated, undermining or asserting the authority of particular actors.

In addition, one perhaps has to mention that the easiness of communication and the interconnectedness of economic ties have led to new paradigms and resources for disseminating religious knowledge ${ }^{64}$. For instance, researchers ${ }^{65}$ refer to the emergence of online magazines such as Q-News and the Muslim news that are 'available to those whose first language is English'.66

As new paradigms for claiming authority have emerged, televangelists have become influential figures to some Muslim audiences, particularly young Muslims of the middle classes ${ }^{67}$. As Lotfy ${ }^{68}$ comments in his exami-

Political Research Meeting, Florence \& Montecatini Terme, 19-23 March, 2003, Robert Schuman Centre for Advanced Studies at the European University Institute; B. S. Turner, "Religious Authority and the New Media", Theory Culture Society 24 (2007), 117.

${ }^{64}$ B.D. Metcalf, "Introduction: Sacred Words, Sanctioned Practice, New Communities”, in Barbara Daly Metcalf (ed.) Making Muslim Space in North America and Europe, Berkeley: University of California Press, 1996, xv; P. Mandaville, "Reimagining Islam in Diaspora..., 173; B.S. Turner, "Religious Authority and the New Media..., 117.

${ }^{65}$ P. Mandaville, "Reimagining Islam in Diaspora..., 173; Martin van Bruinessen, “ Making and Unmaking Muslim Religious Authority in Western Europe”, Paper presented at the Fourth Mediterranean Social and Political Research Meeting, Florence \& Montecatini Terme, 19-23 March, 2003, Robert Schuman Centre for Advanced Studies at the European University Institute; B. S. Turner, "Religious Authority and the New Media", Theory Culture Society 24 (2007).

${ }^{66}$ P. Mandaville, "Reimagining Islam in Diaspora..., 173.

${ }^{67}$ J.D. Howell, "Modulations of Active Piety: Professors and Televangelists as Promoters of Indonesian 'Sufisme”, in G. Fealy and S. White, Expressing Islam: Religious Life and Politics in Indonesia, Institute of Southeast Asian Studies, 2009, 40-62; W. Lotfy, The Phenomenon of Televangelists, Cairo, Egypt: Dar El Ein, 2009.

68 3W. Lotfy, The Phenomenon of Televangelists..., 19-25. 
nation of televangelism in Egypt, youth of upper and middle-classes are attracted to televangelists' discourses because, these social strata do not lack wealth or capabilities and to them the concept of 'civic responsibility' is more appealing than the radical messages of Islamist ideologies. In other words, audiences in Indonesia listening to Aa Gym would relate religion to personal and social development at the same time when audiences listening to Amr Khaled in Egypt are pushed towards the possibility of bringing change to themselves and others.

\section{Conclusion: critique of tele vangelism}

To conclude, in this study, I have delineated the main characteristic features of televangelism in terms of the modern appearance of televangelists, their use of entertainment elements and presenting religion as a force of individual change. I focused on two televangelists, i.e. Amr Khaled and Hamza Yusuf, as two case studies. While televangelism is essentially a 'television-related' genre, ${ }^{69}$ I have argued that the use of digital media by televangelists has helped popularize their discourses (e.g. recordings and TV programmes).

Relevant to the above is the deconstruction of traditional sources of religious authority in which digital media tools have opened up new paradigms and spaces where voices compete for authority and where religious views are negotiated and contested. The Fatwa issued by the European Council for Fatwa and Research allowing housing loans is an example.

The popularity that some televangelists have acquired, particularly attracting the younger generations of Muslims, raises the important question as to how one can evaluate this phenomenon. One has to point

\footnotetext{
${ }^{69}$ R. Frankl, Televangelism: The Marketing of Popular Religion, The United States of America: Southern Illinois University Press, 1987; S. Bruce, Pray TV: Televangelism in America, London: Routledge, 1990.
} 
IJIMS, Indonesian Journal of Islam and Muslim Societies, Volume 4, Number 2, December 2014: 189-211

here that any critique of this phenomenon has to take into consideration its complexity. As a media genre, televangelism is an example of the predominance of the culture of 'info-tainment' that has infiltrated not only the domains of politics ${ }^{70}$ but also religion.

In this vein, 'info-tainment' has triggered varied attitudes from media critics $^{71}$. For instance, in her research on 'politicotainment', or the blurring between politics and entertainment, Van Zoonen (2005) states that 'the celebrity politician of television does not have to depend on anyone else except his own talent as a performer'. ${ }^{72}$ In her book Politics as Usual, Wodak (2009) suggests that the 'fictionalization' of politics in the popular TV series The West Wing is an indication of audiences' disillusionment with politics and their cynicism about politicians' ability to make decisions. ${ }^{73}$

Perhaps Holly (2008), if compared to van Zoonen (2005), seems to be more sympathetic towards infotainment. While he remarks that dramatization and aestheticization are salient features of infotainment, he argues that these elements have to be evaluated separately as to whether they function merely as 'packaging' elements or if they can be seen as 'stimulating, enriching and facilitating comprehension' ${ }^{74}$

As a religious phenomenon, televangelism- with its focus on individual change- ties in with the rise of modern forms of spiritualities ${ }^{75}$. In fact,

\footnotetext{
${ }^{70}$ See R. Wodak, The Discourse of Politics in Action: Politics as Usual, Basingstoke: Palgrave Macmillan, 2009.

${ }^{71}$ L. Van Zoonen, "Imagining the Fan Democracy" European Journal of Communication 19 (2004), 39-52. L.Van Zoonen, Entertaining the Citizen: When Politics and Popular Culture Converge, New York: Rowman \& Littlefield, 2005; R. Wodak, The Discourse of Politics in Action: Politics as Usual, Basingstoke: Palgrave Macmillan, 2009.

${ }^{72}$ L.Van Zoonen, Entertaining the Citizen: When Politics and Popular Culture Converge, New York: Rowman \& Littlefield, 2005, 79.

${ }^{73}$ L.Van Zoonen, Entertaining the Citizen..., 20.

${ }^{74}$ L.Van Zoonen, Entertaining the Citizen..., 328.

75 V.J. Miller, Consuming Religion: Christian Faith and Practice in a Consumer Culture, New York: Continuum, 2004; Carrette and King, 2005.
} 
Carrette and King (2005) made a distinction between (old) 'revolutionary or anti-capitalist spiritualities', exemplified in Buddhist notions of soothing the suffering of others or Islamic notions of just economy; and modern forms of spiritualities. The old spiritualities seem to address 'structural and social inequalities', whereas contemporary spiritualities are taken over -in their many configurations- by the consumer capitalist ideology. ${ }^{76}$ In other words, according to Carrette and King (2005), rather than being a 'critical reflection' of the consumer culture, modern spiritualities seem to act as a 'perpetuation of the consumer status quo' 77 as they 'smoothed out resistance to the growing power of corporate capitalism and consumerism as the defining ideology of our time'. ${ }^{78}$

I argue in this paper that there are many layers of context to the phenomenon of televangelism (e.g. info-tainment; socio-historical context of Muslims; rise of spiritualities) that any 'holistic' evaluation of it in terms of being 'negative' or 'positive' will be simplistic. Rather, I argue for an approach that examines particular case studies of televangelists, deconstructing how structures of power are represented in their discourses. This will enable us to answer the question, inter alia, if particular televangelists' messages 'smoothe out' capitalist inequalities, to use term by Carrette and King (2005), or if particular televangelists are critical of the status quo in a broad sense of the term (e.g. critical of gender inequalities and socio-economic injustices).

Critical Discourse Analysis that looks into the relationship between language, power and ideology can provide a useful framework ${ }^{79}$. For in-

${ }^{76}$ Carrette and King, 2005, 7-21.

77 Carrette and King, 2005, 23.

${ }^{78}$ Carrette and King, 2005, 11.

${ }^{79}$ See N.L. Fairclough and R. Wodak, "Critical Discourse Analysis", in T. A. van Dijk (ed.), Discourse Studies A Multidisciplinary Introduction, Vol. 2. Discourse as Social Intercation. London: Sage, 1997, 258-84. 
stance, in the Discourse Historical Approach, texts are examined synchronically (i.e. at the present time) and diachronically, relating the text to the broader socio-historical contexts ${ }^{80}$. Through a Critical Discourse Analysis approach to televangelists' texts ${ }^{81}$, one can get a nuanced understanding of how the sermons and texts of particular televangelists, can possibly relate to dominant (capitalist) ideologies, how structures of power are represented in their discourses and what their texts may reveal about the socio-historical contexts of Muslims in the twenty first century.

\section{Bibliography}

Baker, P., Gabrielatos, C. \& McEnery, T. Discourse Analysis and Media Attitudes: The Representation of Islam in the British Press. Cambridge:

Cambridge University Press, 2013.

Bruinessen, M. van, "Making and unmaking Muslim religious authority in Western Europe", Paper presented at the Fourth Mediterranean Social and Political Research Meeting, Florence \& Montecatini Terme, 19-23 March, 2003, Robert Schuman Centre for Advanced Studies at the European University Institute.

Bunt, G. Islam in the Digital Age: E-jihad, Online Fatwas and Cyber Islamic Environments. London: Pluto Press, 2003.

Bunt, G. "Rip. Burn. Pray: Islamic Expression Online", in Dawson, L. L. and D. E. Cowan (eds.). Religion Online: Finding Faith on the Internet. London and New York: Routledge, 2004: 123-134.

Burgess, J. and J. Green. You Tube: Online Video and Participatory Culture. Cambridge: Polity, 2009.

Bruce, S. Pray TV: Televangelism in America. London: Routledge, 1990.

Campbell, H. A. When Religion Meets New Media. London: Routledge, 2010. Campbell, H.A., "Understanding the Relationship between Religion

Online and Offline in a Networked Society", Journal of the American Academy of Religion, Vol. 80, No. 1 (2012): 64-93.

${ }^{80}$ See R. Wodak, "The Discourse-Historical Approach", in R. Wodak and M. Meyer (eds.), Methods of Critical Discourse Analysis, London: SAGE, 2001, 63-94; 67-73

${ }^{81}$ e.g. sermons, TV interviews, social media posts. 
Castells, M. The Rise of the Network Society. Oxford: Basil Blackwell, 1997.

Echchaibi, N. "From audio tapes to video blogs: the delocalization of authority in Islam", Nations and Nationalism, Vol. 17, No. 1 (2011): 25-44.

Eickelman, D.F., "The Study of Islam in Local Contexts", Contributions to Asian Studies 17 (1982).

El-Nawawy, M. and S. Khamis. Islam Dot Com: Contemporary Islamic Discourses in Cyberspace. New York: Palgrave Macmillan, 2009.

Esposito and Kalin (eds.). The 500 Most Influential Muslims in the World. Amman: The Royal Islamic Strategic Studies Centre, 2009.

Fairclough, N. L. and Wodak, R., "Critical discourse analysis", in T. A. van Dijk (ed.). Discourse Studies A Multidisciplinary Introduction, Vol. 2. Discourse as Social Intercation. London: Sage, 1997: 258-84.

Frankl, R. Televangelism: The Marketing of Popular Religion. The United States of America: Southern Illinois University Press, 1987.

Gilliat-Ray, S. Muslims in Britain: An Introduction. Cambridge: Cambridge University Press, 2010.

Haddad, Y. Y. and J.I. Smith (eds.). Muslim Minorities in the West: Visible and Invisible. Oxford: Altamira Press, 2002.

Helland, C., "Popular religion and the World Wide Web: A match made in (Cyber) Heaven”, in Dawson, L. L. and D. E. Cowan. Religion Online: Finding Faith on the Internet. London and New York: Routledge, 2004: 23-36.

Hinnells, J. R., “The study of diaspora religion”, in Hinnells, J. R. (ed.). The Penguin handbook of the world's living religions. London: Penguin, 2010: 682-689.

Holly, W., "Tabloidization of Political Communication in the Public Sphere", in R. Wodak and V. Koller (eds.). Communication in the Public Sphere: Handbook of Applied Linguistics (Vol 4). Berlin: De Gruyter, 2008: 31742.

Howell, J. D., "Modulations of active piety: Professors and televangelists as promoters of Indonesian 'Sufisme'", in Fealy, G. and S. White. Expressing Islam: Religious Life and Politics in Indonesia. Institute of Southeast Asian Studies, 2008: 40-62.

Jaffe, A. Modernism and the Culture of Celebrity. Cambridge: Cambridge University Press, 2005.

Juergensmeyer, M. (ed.) Global Religions: An Introduction. Oxford: Oxford University Press, 2003.

Kellner, D. Media Spectacle. London and New York: Routledge, 2003. 
IJIMS, Indonesian Journal of Islam and Muslim Societies, Volume 4, Number 2, December 2014: 189-211

Keen, A. How Today's Internet is killing Our Culture and Assaulting Our Economy. Great Britain: Nicholas Brealey Publishing, 2007.

Kutscher, J., "The Politics of Virtual Fatwa Counseling in the 21st Century", Masaryk University Journal of Law and Technology, Vol. 3, No. 1 (2009): 33 50 .

Lotfy, W. The Phenomenon of Televangelists. Cairo, Egypt: Dar El Ein, 2009.

Mandaville, P., "Reimagining Islam in Diaspora: The Politics of Mediated Community”, International Communication Gazette, Vol. 63 No. 2-3 (2001): 169-186.

Mandaville, P., "'Towards a critical Islam: European Muslims and the changing boundaries of transnational religious discourse", in Allievi, S. and J. Nielsen (eds.). Muslim Networks and Transnational Communities in and across Europe. Leiden: Brill, 2003.

Mandaville, P. Global Political Islam. London: Routledge, 2007.

Metcalf, B.D., "Introduction: Sacred Words, Sanctioned Practice, New Communities", in Barbara Daly Metcalf (ed.). Making Muslim Space in North America and Europe. Berkeley: University of California Press, 1996.

Miller, V. J. Consuming Religion: Christian Faith and Practice in a Consumer Culture. New York: Continuum, 2004.

Muchnik, M., "Discourse strategies of Maxzirim Bitshuva: The case of a repentance preacher in Israel”, Text, Vol. 25, No. 3 (2005): 373-398.

Neuman, Y., Y. Lurie and M. Rosenthal, "A Watermelon without seeds: A case study in rhetorical rationality", Text, Vol. 21, No. 4 (2001): 543 565 .

Rockwell, D. and D. C. Giles, "Being a Celebrity: A Phenomenology of Fame", Journal of Phenomenological Psychology 40 (2009): 178-210.

Robinson, F., "Islam and the Impact of Print", Modern Asian Studies, Vol. 27, No. 1 (1993): 229-251.

Rose, G. Visual Methodologies: an Introduction to the Interpretation of Visual Materials (2nd ed.). Sage, 2007.

Schmidt, G., "The Transnational Umma- Myth or Reality? Examples from the Western Diasporas", The Muslim World 95 (2005): 575-586.

Sisler, V., "The Internet and the construction of Islamic knowledge in Europe”, Masaryk University Journal of Law and Technology, Vol. 1, No. 2 (2007).

Tartoussieh, K., "Muslim digital Diasporas and the gay pornographic cyber imaginary", in Alsultany, E. and E. Shohat (eds.). Between the Middle East and the Americas: The Cultural Politics of Diaspora. USA: University of Michigan Press, 2013: 214-230. 
Thomas, G., "A Typology for the Case Study in Social Science Following a Review of Definition, Discourse And Structure", Qualitative Inquiry, Vol. 17, No. 6 (2011): 511-521.

Turner, B. S., "Religious Authority and the New Media", Theory Culture Society 24 (2007): 117.

Van Zoonen, L., "Imagining the Fan Democracy", European Journal of Communication 19 (2004): 39-52.

Van Zoonen, L. Entertaining the Citizen: When Politics and Popular Culture Converge. New York: Rowman \& Littlefield, 2005.

Wise, L. "Words from the Heart: New Forms of Islamic Preaching in Egypt", Masters thesis, St Anthony's College, University of Oxford, 2003. Available at: http://users.ox.ac.uk/ ${ }^{\sim}$ metheses/WiseNoImages.pdf (accessed 22nd February 2014).

Wodak, R., "The Discourse-Historical Approach", in Wodak, R. and M. Meyer (eds.). Methods of Critical Discourse Analysis. London: SAGE, 2001: 63-94.

Wodak, R. The Discourse of Politics in Action: Politics as Usual. Basingstoke: Palgrave Macmillan, 2009.

Wodak, R. and M. Meyer (eds.). Methods of Critical Discourse Analysis. London: SAGE, 2009.

Wodak, R., Mral, B., \& Khosravinik, M. (eds.). Right Wing Populism in Europe: Politics and Discourse. London: Bloomsbury Academic, 2013. 